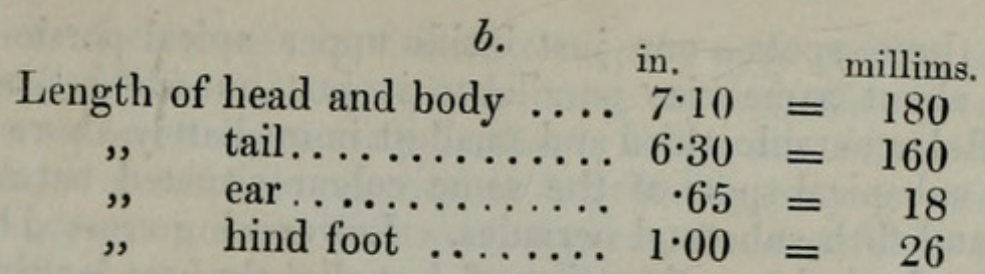

Hab. Cape York, Queensland (Damen, Mus. Brit.).

Dr. Jentink's Celebes Mouse, my Mus browni from Duke-of-York Island $^{1}$, and $M$. terra-regince, are all nearly related, although perfectly distinct; and allied species will doubtless be discovered in other parts of the Eastern Archipelago.

\title{
4. On some African Species of the Lepidopterous Genus Papilio. By W. L. Distant.
}

[Received June 7, 1879.]

\section{(Plate XLVII.)}

The following short paper gives some notes taken during an examination recently made of the fine collection of African Papiliones in the collection of Mr. F. J. Horniman. Most of the WestAfrican specimens have been obtained from the Calabar district (Isubu, Mongo-ma-lobah, Calabar) ; and these are peculiarly interesting as marking a district of which the insect fauna differs in many slight respects, though seldom specifically, from that of the neighbouring district of the Gold Coast. I have been forced to this conclusion not only from the examination of the Butterflies of this genus, but from having already worked out large collections of Hemiptera from the same locality, and from information supplied me by accomplished Coleopterists as to the insects of their own order. From Sierra Leone the divergence of the Calabar district is much greater, many insects being peculiar to each locality.

\section{Papilio ophidocephalus, Oberthur, Études d'Entomologie,} p. 13 (1878).

M. Oberthur has given the above name to the S.-African form figured by Trimen as P. menestheus (Rhop. Afr.-Austr. t. 2. f. 1). A long series in this collection from both S. and E. Africa shows the characters to be quite constant; and a $\$ P$. menestheus from the Calabar district agrees with the typical characters of the $\delta$ of that species as figured by Drury.

\section{Papilio hornimani, n. sp. (Plate XLVII. figs. 1, 2 $\boldsymbol{\delta}^{*}, 3$ ․)}

$0^{*}$. Wings above black, marginal fringe streaked with pale sulphuryellow. Fore wings with a straight, oblique, transverse, green fascia, only divided by the nervules, extending from just inside lower apical portion of discoidal cell to about centre of interior margin. Above

$$
{ }^{1} \text { P.Z.S. 1877, p. } 123 .
$$


this are three spots-one just inside upper apical portion of cell, another about same size parallel to it just outside cell and upper disco-cellular nervule, third and smallest immediately above secondand two subapical spots of the same colour situated between third, fourth, and fifth subcostal nervules. Lower wing crossed by a green transverse fascia in continuation of, but slightly broader than that of the fore wing, toothed externally, extending through and beyond apical third of cell to near centre of abdominal margin, where it is again somewhat narrower. A submarginal row of nine rounded green spots situated one below first subcostal nervule, two wide apart te:ween second subcostal nervule and discoidal nervule, and the other six in pairs closer together divided by the median nervules.

Underside with the ground-colour and markings much as in $P$. charopus, West., but upper wings with a submarginal row of four large, crescent-shaped sulphureous patches, situated between the second discoidal nervule and the first, second, and third median nervules. Lower wings with a submarginal row of twelve bright sulphur-coloured spots, situated in pairs between the nervules, and two others of the same colour, one at aual angle and one near lower fourth of abdominal margin.

․ Above generally as in $\delta$. Underside with the four submarginal, sulphureous, crescent-shaped patches to fore wings, but the spots on the hind wings very obscure.

Exp. wings, ot $4 \frac{1}{2}$ in., of $4 \frac{8}{10}$ in.

Hab. Magila, East Africa.

Allied to $P$. charopus, West., from which it is at once distinguished by the narrow discal fasciæ above and the different and bright sulphureous markings beneath.

Papilio thersander, Fab. Ent. Syst. iii. i. p. 32, n. 93 (1793); West. Arc. Ent. i. t. 38. f. J, 2 (1842).

Mr. Kirby in his 'Catalogue Diurn. Lepid.' p. 563, places this species as the female of $P$. phorcas, Cram. Mr. Horniman's collection, however, contains two male and two female specimens of $P$.thersander; and therefore such cannot be the case. The females agree with Westwood's figure beneath better than above, the transverse macular band of the fore wings being much more broken than is portrayed in that figure. The male differs from the female in having all the macular markings pale yellow instead of creamy white. The male specimens are localized "Aburie, Accra." The female specimens have no locality affixed.

Papilio cypreafila, Butl. Ent. Mo. Mag. v. p. 60 (1868).

P. zenobia, Don. Nat. Rep. v. t. 179 (1827); Luc. Lép. Ex. t. 24. f. 1 (1835).

All the specimens of the above species in this collection received from Isubu, Mongo-ma-lobah, and Calabar agree with the figure of Lucas and differ from that of Donovan (who records his specimen from Sierra Leone) in the smaller size of the marginal white incisures to the hind wings and also in the shape and size of the broken macular 
fascia of the fore wings, in this last respect approaching somewhat $P$. odenatus, West. One specimen, however, from the above district, but unfortunately not precisely localized, differs so much that though, judging from one specimen only, it is probably only a variety of $\boldsymbol{P}$. cypreafila, yet, as Prof. Westwood regards $P$.odenatus as requiring a specific name, I have followed him (for the sake of uniformity in the nomenclature of these closely allied forms) in distinguishing this apparent variety by a name also :-

Var. gallienus, Dist.

Differs from P. cypraafila in the much narrower central fascia of the hind wings, which is only 8 millims. wide, and in the smaller and more divided spots of the macular fascia of the fore wings. These fasciæ and marginal incisures àre also of a pale-lemon hue.

Papilio zalmoxis, Hew. Ex. Butt. iii. Pap. t. 6. f. 18 (1864).

One specimen from $R$. Ogowai (Nassau) is remarkable for its smaller size, $5 \frac{1}{10}$ inch, rather more than 1 inch less in expanse than type and ordinary specimens. The ground-colour of the underside of posterior wings is also darker ferruginous.

Papilio horribilis, Butl. Lep. Ex. p. 88, t. 34. f. 2 (1872).

Var. calabaricus, Dist.

This variety differs chiefly from Butler's figure in the submarginal row of five spots to the posterior wing. The upper three are very small; but of these the central one is much the largest and the third the smallest and indistinct (sometimes wanting); fourth and fifth very much the largest, fifth much smaller than fourth. A red spot on lower portion of abdominal margin. The median fascia to hind wings is generally narrower and straighter than in P. horribilis, but in one specimen agrees in that respect with Butler's figure. I have examined thirteen specimens, and, finding these characters constant, have distinguished it as a variety of $P$. horribilis, though probably it should be more correctly called a distinct "local race."

Isuba, Mongo-ma-lobah.

5. Note on the Mechanism of Respiration as well as of the Retraction of the Head and Limbs in certain Chelonia. By A. H. Garrod, M.A., F.R.S.

[Received June 13, 1879.]

For some time past $I$ have been acquainted with the fact that in Tortoises the movement of the limbs influences the degree of inflation of the lungs; and on one occasion I have been able, in a dead specimen of a large species, to blow out a candle by means of the current of air issuing from the nostrils consequent upon my forcibly pushing inwards one of the previously extended anterior limbs. From this I inferred that the rigidity of the thoracic and abdominal walls (which entirely precludes their being employed in respiration) is made up for by the 


\section{$2 \mathrm{BHL}$ Biodiversity Heritage Library}

Distant, William Lucas. 1879. "On some African species of the Lepidopterous Genus Papilio." Proceedings of the Zoological Society of London 1879, 647-649.

View This Item Online: https://www.biodiversitylibrary.org/item/90455

Permalink: https://www.biodiversitylibrary.org/partpdf/67262

\section{Holding Institution}

Natural History Museum Library, London

\section{Sponsored by}

Natural History Museum Library, London

\section{Copyright \& Reuse}

Copyright Status: Public domain. The BHL considers that this work is no longer under copyright protection.

This document was created from content at the Biodiversity Heritage Library, the world's largest open access digital library for biodiversity literature and archives. Visit BHL at https://www.biodiversitylibrary.org. 